
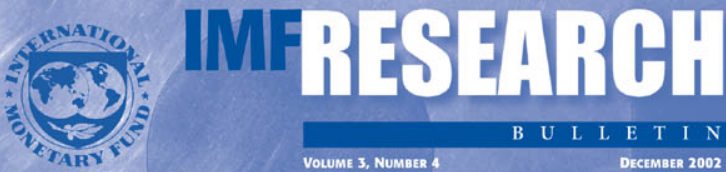

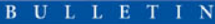

VoLUme 3, Numser 4

DECEMBER 2002

\section{Editor's Note}

The first article in this issue is on conditionality, a subject that is at the core of the IMF's lending programs, The second article surveys IMF research on the relationship between public policies and the United Nations Millennium Development Goals. The large body of theoretical and empirical research by IMF staff on these topics serves as an indicator of how analytical work informs and guides the IMF's surveillance and program work in its member countrics. The country/area study in this issue is on Hong Kong SAR. Also included are summaries of the latest Worhl Economic Outlook and two recent IMF conferences.

Change of Editor

Since its inception in June 2000 , the Research Bulletin has garnered a worldwide readership of more than 20,000 academics and policymakers. 1 hope that, during this period, the Bulletin has served to highlight the breadth and quality of IMF research and shown how it forms the analytical backbone for the operational work of the institution.

For their support in the concep. tion and operation of the Bulletin. I am grateful to Stanley Fischer. Michael Mussa, and Kenneth Rogoff. The editorial team (page 11) continues to do a fine job. And I thank the authors who, through their valuable contributions, make the Bulletin the widely read publication that it is.

The Research Bulletin will be under new editorship in 2003.

- Eswar S. Prasad

\title{
Research Summaries
}

\section{IMF Conditionality and Country Ownership of Reforms}

Alex Mourmouras

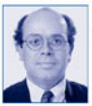

The policies that countries agree to follow as a condition for borrowing from the IMF-conditionality, for shert-are at the heart of the IMF's operations. Recent IMF researdh has forcused on how conditionality, and the LMF's process of interaction with borrowing cotentries, more generally, affect their commitment to implementing neforms. Theoretical rescarch has strosed how strategic interactions between the IMF, borrowing governments, and orher domestic actors that exert political influence have impacted ownership of reforns. Intproventents in measuring conditionality have also made possible more rigorous empirical testing of the links between conditionality, the characteristics of borrowing countries, and the implementation and economic conseyuences of IMF-supported programs.

(continued on page 2)

\section{Public Policies and the Millennium Development Goals}

Luiz de Mello

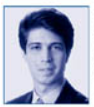

In September 2000, the member states of the United Nations underscored the importance of sustainable development by reaffirming the Millennium Development Goals (MDGs)—a set of time-bound targets for improving human development. The MDGs are multidimensional and focus on eradicating extreme poverty and hunser; achicving universal primary educations, promoting gernier equality and women's empowerment; reducing child martality; improving maternal health; combating HIV/AIDS, malaria, and other diseases ensuring envinonmental sustainability; and developing a global parmersitip for development. There has been a growing body of IMF research on public policies that could contribute to adhicvement of the MDGx

(continued on page 5)

\section{In This Issue}

IMF Conditionality and Country

Ownership of Reforms

Public Policies and the MDGs

IMF Staff Papers Contents

Third Annual Research

Conference

Country/Area Study:

Hong Kong SAR
Conference on Central

Banking Challenges

Globalization in Historical

2 Perspective

IMF Working Papers

Visiting Scholars

8 World Economic Outlook 


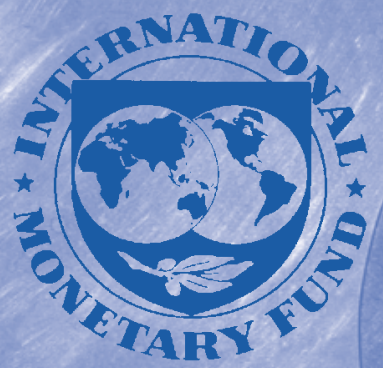

\section{Editor's Note}

The first article in this issue is on conditionality, a subject that is at the core of the IMF's lending programs. The second article surveys IMF research on the relationship between public policies and the United Nations Millennium Development Goals. The large body of theoretical and empirical research by IMF staff on these topics serves as an indicator of how analytical work informs and guides the IMF's surveillance and program work in its member countries. The country/area study in this issue is on Hong Kong SAR. Also included are summaries of the latest World Economic Outlook and two recent IMF conferences.

Change of Editor

Since its inception in June 2000, the Research Bulletin has garnered a worldwide readership of more than 20,000 academics and policymakers. I hope that, during this period, the Bulletin has served to highlight the breadth and quality of IMF research and shown how it forms the analytical backbone for the operational work of the institution.

For their support in the conception and operation of the Bulletin, I am grateful to Stanley Fischer, Michael Mussa, and Kenneth Rogoff. The editorial team (page 11) continues to do a fine job. And I thank the authors who, through their valuable contributions, make the Bulletin the widely read publication that it is.

The Research Bulletin will be under new editorship in 2003. —Eswar S. Prasad

\section{Research Summaries}

\section{IMF Conditionality and Country Ownership of Reforms}

Alex Mourmouras

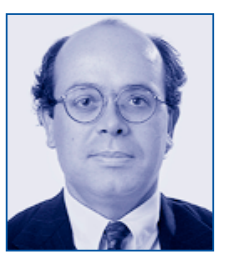

The policies that countries agree to follow as a condition for borrowing from the IMF-conditionality, for short—are at the heart of the IMF's operations. Recent IMF research has focused on how conditionality, and the IMF's process of interaction with borrowing countries, more generally, affect their commitment to implementing reforms. Theoretical research has stressed how strategic interactions between the IMF, borrowing governments, and other domestic actors that exert political influence have impacted ownership of reforms. Improvements in measuring conditionality have also made possible more rigorous empirical testing of the links between conditionality, the characteristics of borrowing countries, and the implementation and economic consequences of IMF-supported programs.

(continued on page 2)

\section{Public Policies and the Millennium Development Goals}

Luiz de Mello

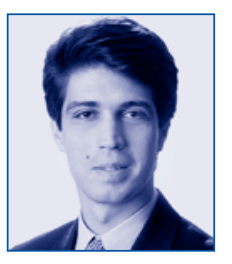

In September 2000, the member states of the United Nations underscored the importance of sustainable development by reaffirming the Millennium Development Goals (MDGs) - a set of time-bound targets for improving human development. The MDGs are multidimensional and focus on eradicating extreme poverty and hunger; achieving universal primary education; promoting gender equality and women's empowerment; reducing child mortality; improving maternal health; combating HIV/AIDS, malaria, and other diseases; ensuring environmental sustainability; and developing a global partnership for development. There has been a growing body of $I M F$ research on public policies that could contribute to achievement of the MDGs.

(continued on page 5)

\section{In This Issue}

\begin{tabular}{|c|c|c|c|}
\hline $\begin{array}{l}\text { IMF Conditionality and Country } \\
\text { Ownership of Reforms }\end{array}$ & & $\begin{array}{l}\text { Conference on Central } \\
\text { Banking Challenges }\end{array}$ & 10 \\
\hline Public Policies and the MDGs & 1 & \multirow{2}{*}{$\begin{array}{l}\text { Globalization in Historical } \\
\text { Perspective }\end{array}$} & \\
\hline IMF Staff Papers Contents & & & 12 \\
\hline Third Annual Research & & IMF Working Papers & 13 \\
\hline comerence & & Visiting Scholars & 15 \\
\hline $\begin{array}{l}\text { Country/Area Study: } \\
\text { Hong Kong SAR }\end{array}$ & 8 & World Economic Outlook & 16 \\
\hline
\end{tabular}




\section{IMF Staff Papers}

\section{Volume 50, Issue 1}

On the Origins of the FlemingMundell Model

James M. Boughton

How Does Privatization Work? Ownership Concentration and Enterprise Performance in Ukraine Alexander Pivovarsky

A Panic-Prone Pack? The Behavior of Emerging Market Mutual Funds Eduardo Borensztein and Gaston Gelos

Aid Volatility: An Empirical Assessment

Ales Bulir and Javier Hamann

Does Monetary Policy Stabilize the Exchange Rate Following a Currency Crisis? Ilan Goldfajn and Poonam Gupta

Tight Money, Real Interest Rates, and Inflation in Sub-Saharan Africa Edward F. Buffie

The Plutocratic Bias in the CPI: Evidence from Spain Mario Izquierdo, Eduardo Ley, and Javier Ruiz-Castillo

IMF Staff Papers, the IMF's scholarly journal, edited by Robert Flood, publishes selected high-quality research produced by IMF staff and invited guests on a variety of topics of interest to a broad audience, including academics and policymakers in IMF member countries. The papers selected for publication in the journal are subject to a rigorous review process using both internal and external referees. The journal and its contents (including an archive of articles from past issues) are available online at the Research at the IMF website at $h t t p: / / w w w . i m f . o r g /$ research.

\section{IMF Conditionality and Country Ownership of Reforms (continued from page 1)}

Country ownership of reforms is the idea that country authorities and other stakeholders will be primarily responsible for the design and implementation of reforms. How country ownership and conditionality are related is one of several important questions: Why is conditionality needed in IMF lending? How can conditionality become a better instrument of aid and development policy? IMF research has attempted to address these questions from different theoretical perspectives. Conditionality provides borrowing countries assurances that they will continue to receive IMF financing if they meet specified conditions, while also providing safeguards to the IMF that borrowers will repay their loans and adjust their policies in ways that are conducive to national and international prosperity. ${ }^{1}$

From the viewpoint of modern political theory, IMF influence on borrowing governments falls within a domestic political context, thereby providing a unifying framework for how to think about conditionality and its limits. ${ }^{2}$

Governments are motivated by self-interest as well as the objective of enhancing social welfare. Political incumbents will not pursue welfare-enhancing reforms advocated by the IMF if the cost, in terms of lost domestic political support, is high relative to the benefits. Domestic interest groups can influence authorities' political cost-benefit calculus through advertising campaigns, contributions to political parties, bribes, and street protests. ${ }^{3}$ While conditional lending shifts the political equilibrium in the direction of better policies, compared with either no IMF assistance or unconditional assistance, it clearly has limits. All aspects of the strategic environment influence conditionality "leverage," including the borrower's systemic importance to the world economy; its weight in the IMF's objective function; the interest rate charged; agenda-setting and other aspects of the negotiating process; and the strength, number, and nature of lobbying groups.

Conditionality must be appropriately tailored to countries' circumstances to pass the political economy test-country ownership after an assessment of political cost/benefit-as well as for reforms to have the maximum possible effectiveness. ${ }^{4}$ In "unquestionably low ownership" cases, the world economy is better off if the IMF interrupts lending. In "questionable" ownership cases, building political support for reforms through persuasion, economic education, and other means can gradually weaken special interests' hold over power. ${ }^{5}$ Big-bang reforms are appropriate when the IMF's leverage is greatest, such as amid crises or when domestic opposition is disorganized. Commitments to international organizations help governments eschew inefficient policy instruments. Resultsbased conditionality and flexible loan tranches improve incentives, although action-based conditionality may be needed to safeguard the integrity of (and maintain popular support for) privatization and other complex reforms. ${ }^{6}$

As information is imperfect or ambiguous in most reforms, the IMF's conditional lending is a useful signaling device. If conditionality has sufficient "bite," only committed governments will sign on to programs, signaling their readiness to undertake reforms and to deter opposition. ${ }^{7}$ The IMF's unmatched access to officials makes it a "confidential advisor" to sovereigns. ${ }^{8}$ The IMF, in 
backing programs with financial resources, underscores the seriousness of reform announcements and enhances the credibility of its advice.

Can extensive agendas of structural reforms get in the way of ownership and effective conditionality? Decision makers tend to favor the status quo when faced with complex and infrequent events and the outcomes cannot be easily predicted. Multistage structural conditionality-conditions the IMF imposes on reforms of the financial, budgetary, trade, or pricing systems - can run against policymakers' preferences, thus adversely affecting ownership and program implementation. ${ }^{9}$ Because cash-strapped governments will sometimes agree to conditionality even if they are not genuinely committed to reforms, lending must be interrupted early if conditions are not met-before countries become heavily indebted and the IMF has to roll over loans and wait for debt restructurings. ${ }^{10}$ Separating the IMF's lending and surveillance functions could reduce reporting biases and ensure stricter enforcement of conditionality.

Does the Fund's conditional lending limit moral hazard and international contagion? Moral hazard and its consequences, for the world's taxpayers, is limited by the IMF's senior creditor status and its excellent record of repayments. ${ }^{11}$ But lending to governments captured by special interests, without strong conditionality, would mean subsidizing the politically powerful at the expense of unorganized domestic taxpayers. Conditionality that links lending in a crisis to policies during normal times mitigates this moral hazard and limits contagion.

More generally, what is the role of conditionality in poverty reduction programs? Donors grant aid under the veil of partial ignorance about recipient governments' intentions and capacity. If the ultimate uses of aid are not completely known, unconditional program support raises social spending but distorts its composition. Conditionality allows donors to screen "worthy" recipients but cannot achieve the full-information outcome. ${ }^{12}$ Aid should be tied to specific projects when recipient governments are poor or of questionable ownership. Program aid has higher monitoring costs but is more flexible and should be granted to relatively affluent governments or those that benefit the poor. ${ }^{13}$

What is the empirical evidence regarding the impact of the IMF's conditional lending on macroeconomic performance? The mere existence of programs is associated with higher output growth and a lower debt-service ratio, although it does not affect inflation. ${ }^{14,15}$ In financially repressed countries, IMF-supported programs are also associated with financial reforms. ${ }^{16}$ When the implementation of program conditionality is considered, it is found to be associated with lower inflation, higher reserve coverage, and a more depreciated real exchange rate. ${ }^{17}$ In transition economies, implementation is also related to growth. ${ }^{18}$ Perhaps surprisingly, better implementation of conditionality is not associated with fiscal improvement or with more predictable aid. ${ }^{19}$

Beneficial effects of IMF-supported programs will not be realized if conditionality is not implemented. Many programs are interrupted amid political or economic turmoil, under circumstances that make agreements on conditionality for new or revised programs impossible. ${ }^{20}$ And countries that come repeatedly to the IMF for financing continue to have larger imbalances than other IMF borrowers. ${ }^{21}$ Poor implementation of conditionality is associated with weak ownership resulting from strong special interests and other domestic political divisions. ${ }^{22}$ Variables controlled by the IMF, including financial and human effort and the breadth and depth of conditionality, do not seem to affect program implementation once domestic political economy variables are taken into account. Implementation is not related to the number of conditions or the number of prior actionsconditions that must be implemented before the IMF commits its financial resources. ${ }^{23,24}$ Structural conditionality does not influence medium-term fiscal developments. ${ }^{25}$

Case study evidence strongly corroborates the importance of ownership in program implementation. ${ }^{26}$ In some countries, the ambivalence of the top political leaders and resistance by senior officials were key to program failures. When lack of political commitment resulted in stop-and-go program cycles, imposing large numbers of prior actions had limited success, pointing to the need for greater selectivity in lending. In other countries, participatory processes that actively involved the country's top leadership were instrumental in overcoming domestic divisions.

The research summarized in this article informed the IMF's latest Conditionality Review, a two-year process that culminated in September 2002 with the Executive Board's adoption of new guidelines on conditionality. The new guidelines, papers prepared by IMF staff as background for the Board discussions, external contributions, and summaries of the Board's discussions can be found at www.imf.org/conditionality.

${ }^{1} \mathrm{IMF}$, "Conditionality in IMF-Supported Programs-Policy Issues," 2001. Available via the Internet at http://www.imf.org/ external/np/pdr/cond/2001/eng/policy/021601.pdf. Mohsin Khan and Sunil Sharma, "IMF Conditionality and Country 
Ownership of Programs," IMF Working Paper 01/142, 2001; Michael Mussa and Miguel Savastano, "The IMF Approach to Economic Stabilization," in NBER Macroeconomics Annual 1999 (Cambridge, MA: MIT Press, 2000), pp. 79-122; James M. Boughton, Silent Revolution: The International Monetary Fund, 1979-1989, Chapter 13 and the references therein (Washington: IMF, 2001); Anne O. Krueger, "Whither The World Bank and the IMF?" Journal of Economic Literature, Vol. 36 (December 1998), pp. 1983-2020; and idem, "IMF Stabilization Programs," in NBER, Economic and Financial Crises in Emerging Market Economies (Chicago: University of Chicago Press, forthcoming).

${ }^{2}$ Gene M. Grossman and Elhanan Helpman, Special Interest Politics (Cambridge, MA: MIT Press, 2001); and Allan Drazen, Political Economy in Macroeconomics (Princeton: Princeton University Press, 2000).

${ }^{3}$ Wolfgang Mayer and Alex Mourmouras, "Vested Interests in a Positive Theory of IFI Conditionality," IMF Working Paper 02/73, 2002; and Allan Drazen, "Conditionality and Ownership in IMF Lending: A Political Economy Approach,” paper presented at the second Annual IMF Research Conference, Washington, DC, November 2001.

4James M. Boughton and Alex Mourmouras, "Is Policy Ownership an Operational Concept," IMF Working Paper 02/72, 2002.

IIbid; and S. Nuri Erbaş, "Primer on Reforms in a Second-Best Ambiguous Environment: A Case for Gradualism," IMF Working Paper 02/50, 2002.

${ }^{6}$ Avinash Dixit, "IMF Programs as Incentive Mechanisms" (unpublished; Washington: IMF); Karin Elborgh-Woytek and Mark Lewis, "Privatization in Ukraine: Challenges of Assessment and Coverage in Fund Conditionality," IMF Policy Discussion Paper 02/7, 2002; Anna Ivanova, "Moving Towards Outcome-Based Conditionality: Implications for the IMF” (unpublished; Madison, WI: University of WisconsinMadison); and Khan and Sharma, 2001.

${ }^{7}$ Rodney Ramcharan, "How Does Conditional Aid (Not) Work?” forthcoming IMF Working Paper.

${ }^{8}$ Pierre Dhonte, "Conditionality as an Instrument of Borrower Credibility," IMF Paper on Policy Analysis and Assessment 97/2, February 1997.

${ }^{9}$ S. Nuri Erbaş, "IMF Conditionality and Program Ownership: A Case for Streamlined Conditionality” (unpublished; Washington: IMF).

${ }^{10}$ Rodney Ramcharan, "Reputation, Debt and Policy Conditionality," forthcoming IMF Working Paper.

${ }^{11}$ Olivier Jeanne and Jeromin Zettelmeyer, "International Bailouts, Moral Hazard and Conditionality," Economic Policy, Vol. 16 (October 2001), pp. 407-32; and Peter Clark and Haizhou Huang, "International Financial Contagion and the IMF: A Theoretical Framework," IMF Working Paper 01/137, 2001.

12Tito Cordella and Giovanni Dell'Ariccia, "Limits of Conditionality in Poverty Reduction Programs," IMF Working Paper 02/115, 2002.
${ }^{13}$ Idem, "Budget Support Versus Project Aid: A Theoretical Appraisal," paper presented at the second Annual IMF Research Conference, Washington, DC, November 2001.

${ }^{14}$ Nadeem Ul Haque and Mohsin S. Khan, "Do IMFSupported Programs Work? A Survey of the Cross-Country Empirical Evidence," IMF Working Paper, 98/169, 1998.

${ }^{15}$ Louis Dicks-Mireaux, Mauro Mecagni, and Susan Schadler, "Evaluating the Effect of IMF Lending to Low-Income Countries," Journal of Development Economics, Vol. 61 (April 2000), pp. 495-526.

16Abdul Abiad and Ashoka Mody, "Status Quo Bias in Financial Reform,” forthcoming IMF Working Paper.

${ }^{17}$ Anna Ivanova, Wolfgang Mayer, Alex Mourmouras, and George Anayiotos, "What Determines the Success or Failure of Fund-Supported Programs?" paper presented at the second Annual IMF Research Conference, Washington, DC, November 2001.

${ }^{18}$ Valerie Mercer-Blackman and Anna Unigovskaya, "Compliance with IMF Program Indicators and Growth in Transition Economies,” IMF Working Paper 00/47, 2000.

${ }^{19}$ Chauling Chen and Alun Thomas, "Evaluating Fund Programs in the 1990s" (unpublished; Washington: IMF); Aleš Bulír and A. Javier Hamann, "How Volatile and Unpredictable Are Aid Flows, and What Are the Policy Implications?" IMF Working Paper 01/167, 2001; Aleš Bulír and Timothy D. Lane, "Aid and Fiscal Management," paper presented at the IMF Conference on Macroeconomic Policies and Poverty Reduction, Washington, DC, March 2002.

${ }^{20}$ Mauro Mecagni, "The Causes of Program Interruptions," in Economic Adjustment and Reform in Low-Income Countries, ed. by Hugh Bredenkamp and Susan Schadler (Washington: IMF, 1999), pp. 215-76.

${ }^{21}$ IMF Independent Evaluation Office, "Evaluation of the Prolonged Use of Fund Resources," September 2002. Available via the Internet at http://www.imf.org/external/np/ieo/2002/ pu/index.htm.

22Anna Ivanova and others, 2001.

${ }^{23}$ Alun Thomas, "Prior Actions-True Repentance? An Evaluation Based on IMF Programs Over the 1992-1999 Period," forthcoming IMF Working Paper.

${ }^{24} \mathrm{IMF}$, "Structural Conditionality in IMF-Supported Programs," 2001. Available via the Internet at http://www.imf.org/ external/np/pdr/cond/2001/eng/struct/cond.pdf.

${ }^{25}$ Aleš Bulí̌ and Soojin Moon, "The Composition of Fiscal Adjustment and Structural Conditionality Under IMFSupported Programs," forthcoming IMF Working Paper.

${ }^{26} \mathrm{IMF}$, "Strengthening Country Ownership of FundSupported Programs," 2001. Available via the Internet at http://www.imf.org/external/np/pdr/cond/2001/eng/strength/ 120501.pdf. Hugh Bredenkamp and Susan Schadler, eds., Economic Adjustment and Reform in Low-Income Countries (Washington: IMF, 1999); and ESAF Evaluation Board, External Evaluation of the ESAF, report by a group of independent experts (Washington: IMF, 1998). 


\section{Public Policies and the Millennium Development Goals (continued from page 1)}

Although the MDGs have been accepted widely as a framework for assessing development progress, as many as 48 indicators have been selected to monitor progress toward achievement of the goals. IMF research has focused on understanding the links between public spending and these social indicators, where health and educational indicators are treated as outcomes and public spending ratios are treated as inputs in a social production function. ${ }^{1}$ An alternative methodology has been proposed more recently, recognizing that no single output indicator perfectly captures the multidimensional nature of unobserved variables such as a population's health or education status. ${ }^{2}$

Improving the education status of the population is a key MDG and IMF research confirms that public spending on education has a positive effect on education indicators. Higher public spending on education tends to be associated with higher school enrollment rates, lower illiteracy rates, and a higher probability that a student will continue on to the fifth grade. ${ }^{3}$ These findings are robust to the inclusion in the regressions of variables that control for other determinants of educational attainment, such as socio-demographic factors (e.g., fertility rates, secondary enrollment rates for girls, and adult illiteracy rates), development proxies (e.g., urbanization rates and GDP per capita), government size (share of total public spending in GDP), and sector-specific indicators (e.g., pupil-teacher ratios, the ratio of outlays on health care to outlays on education, measuring the composition of social spending, and the ratio of public spending on education per pupil in primary and tertiary education).

The intrasectoral composition of social expenditures (between primary and tertiary education, and curative and preventive care, for instance) affects the correlation between spending and outcomes, especially in poorer countries. In these countries, in particular, investing in basic education can have a positive impact on the population's health status through reduced illiteracy and better access to public social services. Also, a large share of budgetary resources in the social sectors is often used for wages, thus displacing budgetary resources that could be allocated to higher productivity, nonwage inputs, such as medicines and textbooks. ${ }^{4}$

Other key MDGs concern the health status of the population. Per capita income is the most important determinant of health indicators. Most crosscountry research shows that public outlays on health care are positively correlated with life expectancy at birth and negatively correlated with malnutrition rates. The latent variable model estimated by Baldacci, Guin-Siu, and de Mello (2002) confirms the correlations estimated using the conventional social production function approach. Recent research has also focused on the correlation between public spending and the health status of the poor. Using disaggregated data on health indicators, Gupta, Verhoeven, and Tiongson (2001) show that public health spending has a positive, stronger correlation with the health status of the poor, who rely more heavily on public provision of services. ${ }^{5}$ Public expenditure on water and sanitation, as well as environment protection, also correlates positively with health indicators. Recent research has also estimated the effects of debt relief under the Heavily Indebted Poor Countries (HIPC) Initiative on public health spending. ${ }^{6}$

\section{Can the Poor Influence Policy? \\ Participatory Poverty Assessments in the Developing World}

\section{Caroline M. Robb}

Explaining how and why poor people should be included in the national policy dialogue is the subject of this new book. A research method called participatory poverty assessment (PPA) includes poor people in poverty analyses, with the objective of having the results influence policy. PPAs contribute to a better understanding of poverty, identification of policy priorities of the poor - and, hence, budget allocations_-and monitoring and evaluation of policy implementation and impact. Results from PPAs have consistently shown that poverty is multidimensional. Problems such as vulnerability, physical and social isolation, insecurity, lack of self-respect, lack of access to information, distrust of state institutions, corruption, and powerlessness can be as important to the poor as low incomes.

The book shows how poor people's priorities often differ from those assumed by policymakers. It then describes how traditional household surveys and PPAs, as well as data gathered by other research methods, can promote a better understanding of the poverty and distributional impacts of macro policies and reforms.

\section{Policy Discussion Paper}

Policy Discussion Paper PDP 02/10 Reviving the Case for GDP-Indexed Bonds Eduardo R. Borensztein and Paolo Mauro 
Indicators of access by the population, especially the poor, to social services also correlate strongly with social outcomes. In many countries, the government will have a central role in ensuring access to services by either providing them itself or financing private-sector provision.

However, a majority of the benefits from public spending on education and health care do not accrue to the poor. ${ }^{7} \mathrm{~A}$ large share of resources is allocated to tertiary education in most countries, which tends to have lower social rates of return than primary education. ${ }^{8}$ Similarly, in the health-care sector, spending on basic preventive health care, such as immunization and prevention of diseases, has a relatively stronger impact on the poor, yet most public health-care outlays were absorbed by curative care (e.g., hospitals and medical equipment) rather than basic and preventive health care.

Recent IMF research has shown that poor governance, particularly corruption, might hamper countries' ability to reach the MDGs through a number of channels. ${ }^{9}$ First, corruption leads to a reallocation of resources to unproductive uses, absorbing resources that might be used for povertyreducing activities. ${ }^{10}$ Second, corruption has been shown to affect the composition of public spending by reducing outlays on operations and maintenance and diminishing the overall quality of public investment spending. ${ }^{11}$ Third, corruption also has an impact on the efficacy and provision of social services, with repercussions for progress in social indicators. ${ }^{12}$ Finally, indices of democracy have also been shown to be correlated with government spending on health care and education. ${ }^{13}$

Following a different branch of the literature, IMF research has focused on the correlation between government policies and poverty, given that poverty reduction is another key MDG. Research in this area has been motivated by the finding in the literature that economic growth alone is not enough to reduce the incidence of poverty, thus creating some justification for the implementation of policies benefiting the poor. This IMF research has highlighted the role of macroeconomic policies, such as low inflation and sound fiscal policies, as important poverty-reducing instruments. ${ }^{14}$ Others have highlighted the role of policies to mitigate the impact of financial crises on the poor. ${ }^{15}$

The implication of this body of research is that increased public spending on poverty-reducing activities, such as education and health care, can lead to better social outcomes. The econometric evidence of a correlation between public spending and social indicators reported in IMF research is being used by researchers outside the IMF to estimate the resources, particularly in terms of debt relief and foreign financial assistance, needed to help countries meet the MDGs. ${ }^{16}$

In any case, the agenda for future IMF research is focused predominantly on further empirical work on the association between public spending and the social indicators selected for monitoring progress toward achieving the MDGs. Data constraints remain an obstacle to more refined hypothesis testing but, as more reliable, higher-quality data become available for a wide enough sample of countries, particularly the less-developed ones, further empirical research is expected to shed more light on the correlation between policy measures and the achievement of the MDGs.

${ }^{1}$ Sanjeev Gupta, Marijn Verhoeven, and Erwin Tiongson, "Does Higher Government Spending Buy Better Results in Education and Health Care?" IMF Working Paper 99/21, 1999 (also published in the European Journal of Political Economy, Vol. 18 (November 2002), pp. 717-37).

2Emanuele Baldacci, Maria Teresa Guin-Siu, and Luiz de Mello, "More on the Effectiveness of Public Spending on Health Care and Education: A Covariance Structure Model," IMF Working Paper 02/90, 2002.

${ }^{3}$ Karnit Flug, Antonio Spilimbergo, and Erik Wachtenheim, "Investment in Education: Do Economic Volatility and Credit Constraints Matter?" Journal of Development Economics, Vol. 55 (April 1998), pp. 465-81.

${ }^{4}$ Paul Glewwe, "Schools and Skills in Developing Countries: Education Policies and Socioeconomic Outcomes," Journal of Economic Literature, Vol. 40 (June 2002), pp. 436-82; and Hong-Sang Jung and Erik Thorbecke, "The Impact of Public Education Expenditure on Human Capital, Growth, and Poverty in Tanzania and Zambia," IMF Working Paper 01/106, 2001.

${ }^{5}$ Sanjeev Gupta, Marijn Verhoeven, and Erwin Tiongson, "Public Spending on Health Care and the Poor," IMF Working Paper 01/127, 2001 (also forthcoming in Health Economics).

${ }^{6}$ Sanjeev Gupta and others, "Debt Relief and Public Health Spending in Heavily Indebted Countries," Bulletin of the World Health Organization, Vol. 80 (February 2002), pp. 151-57; and Hemamala Hettige, Muthukumara Mani, and David Wheeler, "Industrial Pollution in Economic Development: The Environmental Kuznets Curve Revisited," Journal of Development Economics, Vol. 62 (August 2000), pp. 445-76.

${ }^{7} \mathrm{Ke}$-young Chu, Hamid Davoodi, and Sanjeev Gupta, "Income Distribution and Tax and Government Social Spending Policies in Developing Countries,” IMF Working Paper 00/62, 2000.

${ }^{8}$ George Psacharopoulos, "Returns to Investment in Education: A Global Update," World Development, Vol. 22 (September 1994), pp. 1325-43.

${ }^{9}$ George Abed and Sanjeev Gupta, eds., Governance, Corruption, and Economic Performance (Washington: IMF, 2002); and Sanjeev Gupta, Hamid Davoodi, and Erwin Tiongson, "Corruption and the Provision of Health Care and Education Services," in Arvind K. Jain, ed., The Political Economy of Corruption (London: Routledge, 2001). 


\footnotetext{
${ }^{10}$ Sanjeev Gupta, Luiz de Mello, and Raju Sharan, "Corruption and Military Spending," IMF Working Paper 00/23, 2000 (also published in the European Journal of Political Economy, Vol. 17

(November 2001), pp. 749-77).

${ }^{11}$ Paolo Mauro, "Corruption and the Composition of Government Spending," Journal of Public Economics, Vol. 69 (June 1998), pp. 263-79; and Vito Tanzi and Hamid Davoodi, "Corruption, Public Investment, and Growth," in The Welfare State, Public Investment and Growth, ed. by H. Shibata and T. Ihori (Tokyo: Springer, 1998).

${ }^{12}$ Sanjeev Gupta, Hamid Davoodi, and Erwin Tiongson, "Corruption and the Provision of Health Care and Educational Services," IMF Working Paper 00/116, 2000 (also published in The Political Economy of Corruption, ed. by A. Jain (London: Routledge, 2001)).

${ }^{13}$ Reza Baqir, "Social Sector Spending in a Panel of Countries," IMF Working Paper 02/35, 2002; and Louis Kuijs, "The Impact of
}

Ethnic Heterogeneity on the Quantity and Quality of Public Spending," IMF Working Paper 00/49, 2000.

${ }^{14}$ Dhaneshwar Ghura, Carlos Leite, and Charalambos

Tsangarides, "Is Growth Enough? Macroeconomic Policy and Poverty Reduction,” IMF Working Paper 02/118, 2002; and Paul Cashin, Paolo Mauro, Catherine Pattillo, and Ratna Sahay,

"Macroeconomic Policies and Poverty Reduction: Stylized Facts and Overview of Research,” IMF Working Paper 01/135, 2001.

${ }^{15}$ Emanuele Baldacci, Luiz de Mello, and Gabriela Inchauste, "Financial Crises, Poverty, and Income Distribution," IMF Working Paper 02/04, 2002.

${ }^{16}$ Sanjeev Gupta and Marijn Verhoeven, "The Efficiency of Government Expenditure: Experiences from Africa," IMF Working Paper 97/153, 1997 (also published in Journal of Policy Modeling, Vol. 23 (May 2001), pp. 433-67).

\section{Third Annual IMF Research Conference Capital Flows and Global Governance}

The third in a series of annual research conferences was held at IMF headquarters in Washington, DC, on November 7-8, 2002. A summary of the proceedings will appear in the next issue of the IMF Research Bulletin. A more detailed program and links to these papers can be found at www.imf.org/research.

\section{IS-LM-BP in the Pampas}

Andrés Velasco (Harvard University), Luis Céspedes (IMF), and Roberto Chang (Rutgers University)

Bond Restructuring and Moral Hazard: Are Collective Action Clauses Costly?

Torbjörn Becker (IMF), Anthony Richards (Reserve Bank of Australia), and Yunyong Thaicharoen (Bank of Thailand)

Banking, External Flows, and Crises

Raghu Rajan and Douglas Diamond (University of Chicago)

Bubbles and Capital Flows

Jaume Ventura (CREI-UPF and MIT)

Keynes, Cocoa, and Copper: In Search of Commodity Currencies

Paul Cashin (IMF), Luis Céspedes (IMF), and Ratna

Sahay (IMF)
Financial Integration and Macroeconomic Volatility M. Ayhan Kose (IMF), Eswar Prasad (IMF), and Marco Terrones (IMF)

Towards a Statutory Approach to Sovereign Debt Restructuring: Lessons from Corporate Bankruptcy Practices Around the World Patrick Bolton (Princeton University)

Securities Transaction Taxes and Financial Markets Karl Habermeier (IMF) and Andrei Kirilenko (IMF)

Global Financial Integration Philip Lane (Trinity College, Dublin) and Gian Maria Milesi-Ferretti (IMF)

The Mundell-Fleming Lecture

Explaining Sudden Stop, Growth Collapse, and BOP Crisis: The Case of Distortionary Output Taxes Guillermo Calvo (Inter-American Development Bank and University of Maryland)

Panel Discussion

Promoting Better National Institutions:

The Role of the IMF

Guillermo Ortiz (Bank of Mexico)

Jeffrey Frankel (Harvard University)

Nancy Birdsall (Center for Global Development)

Jeffrey Sachs (Columbia University) 


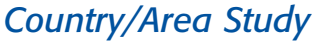 \\ Hong Kong SAR}

Dora M. lakova

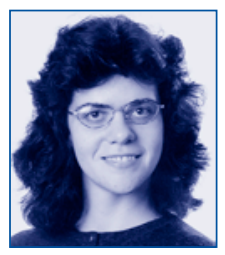

The past two decades have been a period of significant structural changes and rapid growth for the Hong Kong Special Administrative Region (HKSAR), driven by increasing economic integration with mainland China. The integration process has accelerated since the economy returned to Chinese sovereignty on July 1, 1997. HKSAR was hit hard by contagion and underwent a painful economic adjustment during the Asian crisis. Before sustained growth could take hold, the global slowdown in 2001 plunged the highly open economy into another recession. This article provides an overview of IMF staff research addressing both the cyclical and structural adjustment challenges facing HKSAR.

Hong Kong SAR follows rules-based macroeconomic policies, the centerpiece of which is a currency board system. The link has underpinned confidence in HKSAR as a stable financial center, and, historically, the economy has adjusted well to external shocks. Deepening economic linkages with mainland China have recently prompted some observers to ask whether a link to the U.S. dollar remains appropriate, and whether HKSAR and mainland China may constitute an optimal currency area (OCA). Liang (1999) bases her study of this question on Robert Mundell's argument that with limited factor mobility and short-run rigidities in wages and prices, regions constitute an OCA if they experience common real disturbances. ${ }^{1}$ Liang argues that HKSAR and mainland China do not satisfy the conditions for currency integration because their real exchange rates have been evolving on divergent time paths, at least until now. Wei and others (2000) simulate the potential effect of a devaluation of the Chinese renminbi on the stability of the Hong Kong dollar. ${ }^{2}$ They find that trade balance effects will be negligible because the benefit from increased re-exports will offset the loss from a decline in direct exports, but the initial market reaction could be negative. Ma, Meredith, and Yiu (2002) construct a model of the currency board to study its stochastic properties under different shocks. ${ }^{3}$

A sound fiscal policy has been another pillar of the rulesbased system. Conservative fiscal management in the past has resulted in the accumulation of large fiscal reserves. However, since the Asian crisis, there has been a sharp deterioration in the fiscal balances, which is partly structural in nature. Gobat (2001) studies the long-term prospects for public finances and finds that, with unchanged policies, there may be a sustained long-run deterioration in the fiscal position stemming from demographic pressures and a narrowing of the tax base. ${ }^{4}$ Therefore, an early start on consolidation would be advisable.

The constraints of the currency board require rapid adjustment of goods and factor prices in response to economic shocks. Lai, Ha, and Leung (2002) find that prices and labor costs adjust more readily in HKSAR than in Argentina. ${ }^{5}$ Starting from the hypothesis that more competitive markets facilitate price adjustment, Zitzewitz (2000) compares profit margins in different sectors, and finds that HKSAR is as competitive as a typical OECD economy. ${ }^{6}$ However, possible imperfect competition in some sectors does not prevent efficient price adjustment-he estimates that markups in HKSAR tend to be more procyclical than in other advanced economies.

HKSAR's labor market is considered among the most flexible in the world. The last two decades witnessed rapid structural changes as manufacturing was gradually outsourced to mainland China, and the share of the service sector increased substantially. Strum (2000) attributes the efficient adjustment of the labor market to these shifts to lack of government intervention, limited means-tested social support for the unemployed, and low unionization. ${ }^{7}$ However, the rapid labor-market adjustment has not been costless. Iakova (2002) finds that labor earnings inequality has risen sharply over the past two decades and is among the highest in the world. ${ }^{8}$ While real wages increased for most workers during this period, the biggest "winners" have been those with higher education, suggesting that policies to address the growing income disparity should be targeted at increasing the skill levels of the labor force.

Property price developments greatly influence investment and consumption decisions in HKSAR_-value added in the property sector accounts for a quarter of the economy's GDP. The mid-1990s witnessed a rapid increase in property prices, fueled by sustained economic growth and low real interest rates. Kalra, Mihaljek, and Duenwald (2000) find evidence that a property-price bubble had developed by 1997. ${ }^{9}$ Indeed, property prices declined sharply in the wake of the Asian crisis and have drifted downward since then.

The collapse of the property-price bubble, and the need to adjust product and factor prices in response to the cyclical downturns, have led to a persistent deflation, which is now in its fourth year. Schellekens (2002) finds that variations in unemployment and credit growth explain the major part of deflation, while a narrowing price differential with mainland China accounts for only a small fraction of the pressure on prices. ${ }^{10}$ Schellekens argues that the persistence of deflation is partly explained by the amplification of the initial price adjustment through large balance-sheet and wealth effects. 
In 1998, the domestic currency came under several waves of intense speculative pressure while, at the same time, the stock market plummeted. The authorities reacted by intervening in the stock market, arguing that the markets had been manipulated. Breuer (2001) uses currency-option prices to extract market expectations of future exchange rate movements around the periods of heavy speculation in August $1998 .{ }^{11} \mathrm{He}$ estimates that market participants attached a very high probability to an imminent collapse of the link, and the controversial government intervention was very successful in allaying devaluation concerns.

The Asian crisis brought major speculative attacks, interest rate hikes, large capital outflows, a sudden burst of the property-price bubble, and sharp output contraction. However, HKSAR banks remained sound and the deterioration of their portfolios was much less pronounced than in other crisis countries. Iakova (2001) finds that the stability of the banking system is supported by prudent bank management, low corporate leverage, a strong legal system, strong banking regulations, competent supervision, a lack of government intervention in lending decisions, good macroeconomic policies, and the stable exchange rate. ${ }^{12}$

Given the importance of continuous development of the financial sector for maintaining HKSAR's competitive advantage, IMF research has examined different aspects of financial market evolution. Lee (2001) and Mendis (2002) find that the most important source of corporate financing is bank credit, followed by equity issuance. ${ }^{13}$ Jiang $(2001,2002)$ and Lee establish that a small domestic investor base, cumbersome listing procedures, and tax distortions are among the reasons for the relative underdevelopment of the bond market and discuss policy changes that could make the bond market more attractive. ${ }^{14}$

The long-term growth outlook for the economy depends on how it meets the challenges of further integration with mainland China. Breuer (2000) evaluates the likely impact on HKSAR of China's membership in the World Trade Organization. He finds that trade creation will likely exceed trade diversion in the medium term. ${ }^{15}$ Wang (2002) emphasizes that in the long term, HKSAR's role as a trade entrepôt is likely to diminish, and substantial restructuring will be required to maintain HKSAR's competitiveness. ${ }^{16}$

${ }^{1}$ Hong Liang, "Do Hong Kong Special Administrative Region and China Constitute an Optimal Currency Area? An Empirical Test of the Generalized Purchasing Power Parity Hypothesis," IMF Working Paper No. 99/79, 1999.

${ }^{2}$ Shang-Jin Wei, Ligang Liu, Zhi Wang, and Wing Woo, "The China Money Puzzle: Will Devaluation of the Yuan Help or Hurt the Hong Kong Dollar?" China Economic Review, Vol. 11 (December 2000), pp. 171-88.
3Yue Ma, Guy Meredith, and Matthew Yiu, "A Currency Board

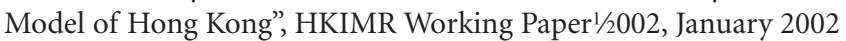
(Hong Kong SAR: Hong Kong Institute for Monetary Research).

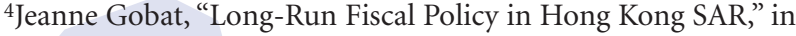
People's Republic of China-Hong Kong Special Administrative Region: Selected Issues and Statistical Appendix, IMF Staff Country Report No. 01/146, 2001.

${ }^{5}$ Kitty Lai, Jiming Ha, and Cynthia Leung, "Comparing Flexibility in Argentina and Hong Kong," HKMA Quarterly Bulletin, May 2002 (Hong Kong SAR: Hong Kong Monetary Authority).

${ }^{6}$ Eric Zitzewitz, "Domestic Competition, Cyclical Fluctuations, and Long-Run Growth in Hong Kong SAR," IMF Working Paper No. 00/142, 2000.

${ }^{7}$ Peter Sturm, "The Hong Kong SAR Labor Market: Key Characteristics, Recent Developments, and Prospects," in People's Republic of China-Hong Kong Special Administrative Region: Selected Issues and Statistical Appendix, IMF Staff Country Report 00/30, 2000.

${ }^{8}$ Dora Iakova, "Trends in Wage Inequality in Hong Kong SAR, 1981-2001," in People's Republic of China-Hong Kong Special Administrative Region: Selected Issues, IMF Staff Country Report 02/99, 2002.

${ }^{9}$ Sanjay Kalra, Dubravko Mihaljek, and Christoph Duenwald, "Property Prices and Speculative Bubbles: Evidence from Hong Kong SAR," IMF Working Paper No. 00/2, 2000.

${ }^{10}$ Philip Schellekens, "Deflation in Hong Kong SAR," in People's Republic of China-Hong Kong Special Administrative Region: Selected Issues, IMF Staff Country Report 02/99, 2002.

${ }^{11}$ Peter Breuer, "Extracting Market Beliefs Around the August 1998 Intervention," in People's Republic of China-Hong Kong Special Administrative Region: Selected Issues and Statistical Appendix, IMF Staff Country Report 01/146, 2001.

${ }^{12}$ Dora Iakova, "How Hong Kong SAR Banks Survived the Asian Crisis," in People's Republic of China-Hong Kong Special Administrative Region: Selected Issues and Statistical Appendix, IMF Staff Country Report 01/146, 2001.

${ }^{13}$ William Lee, "Hong Kong SAR's Debt Market," in People's Republic of China-Hong Kong Special Administrative Region: Selected Issues and Statistical Appendix, IMF Staff Country Report 01/146, 2001; Chandima Mendis, "The Structure and Financing Patterns of the Hong Kong SAR Capital Market," in People's Republic of China-Hong Kong Special Administrative Region: Selected Issues, IMF Staff Country Report 02/99, 2002.

${ }^{14}$ Guorong Jiang, Nancy Tang, and Eve Law, "Cost-Benefit Analysis of Developing Debt Markets," HKMA Quarterly Bulletin, November 2001 (Hong Kong SAR: Hong Kong Monetary Authority); idem, "Hong Kong Dollar Debt Market Developments in 2001," HKMA Quarterly Bulletin, February 2002; and Hong Kong Monetary Authority, "Hong Kong Dollar Debt Market Developments in 2000," HKMA Quarterly Bulletin, February 2001.

${ }^{15}$ Peter Breuer, "A Note on the Impact of Mainland China's Accession to the WTO on Hong Kong SAR," in People's Republic of China-Hong Kong Special Administrative Region: Selected Issues and Statistical Appendix, IMF Staff Country Report 00/30, 2000.

${ }^{16}$ Tao Wang, "Economic Integration Between Hong Kong SAR and the Mainland of China," in People's Republic of China-Hong Kong Special Administrative Region: Selected Issues, IMF Staff Country Report 02/99, 2002. 


\title{
Conference on Challenges to Central Banking from Globalized Financial Systems
}

\author{
Summary by Andrea Schaechter, Mark Stone, and Marco Arnone
}

For central banks seeking to preserve or to attain low inflation and financial stability, increasing global financial market integration presents new challenges. What is the appropriate nominal anchor for countries susceptible to shifts in capital flows? What can central banks do to prevent crises, or to deal decisively with ones that do occur? To address these and related questions, the IMF Monetary and Exchange Affairs Department and the IMF Institute jointly hosted a conference in September 2002 on Challenges to Central Banking from Globalized Financial Systems, which was attended by central bank governors and senior officials from over 45 countries. The gathering highlighted the difficult decisions central bankers face when the twin objectives of monetary and financial stability come into conflict.

Choosing the right exchange rate regime is a traditional dilemma central banks face. Richard Webb (Central Reserve Bank of Peru) observed that there are additional complications, though, when a country has a partially dollarized economy. For Peru, the limited use of U.S. dollars for transactions and wages (currency substitution or real dollarization) coupled with the vulnerability of Peru's open economy to external shocks suggested that a floating exchange rate would be appropriate. But with a large share of private sector liabilities denominated in U.S. dollars (financial dollarization), a large depreciation could translate into financial instability, and that implies a fixed exchange rate is best. In Peru's case, monetary policy options are further constrained by a lack of domestic-currency-denominated financial instruments. Webb noted that Peru has been able to adopt a floating exchange rate and an explicit inflation targeting framework because its low degree of real dollarization — and thus low "pass-through" from exchange rate movements to domestic prices-allows an independent monetary policy. Alain Ize (IMF) remarked that dollarization can build in a vicious circle from currency instability to financial instability to excessive foreign exchange intervention, which can lead to more dollarization. For dollarization to be "cured," a gradual commitment to the currency in the form of an inflation target and better prudential regulation are needed.

The challenges for monetary policy from globalized financial markets may enhance the advantages of monetary unions, but this option comes with its own set of practical difficulties, according to Gert Jan Hogeweg (European Central Bank). He laid out a list of preconditions for the success of a monetary union such as the creation of common market, harmonized legal systems, areawide large value payment systems and security settlement systems, economic convergence, fiscal consoli- dation, and the creation of an independent central bank with a clear monetary policy framework. In particular, the importance of the latter two conditions for the success of a monetary union was also highlighted by K. Dwight Venner (Eastern Caribbean Central Bank).

There are special challenges, too, for countries that want to use an inflation target as an anchor for monetary policy but cannot fully commit to a full-fledged inflation targeting regime. Mark Stone (IMF), in his presentation, termed this policy option "inflation targeting lite." Countries that opt for inflation targeting lite generally aim to bring inflation down to single digits and maintain financial stability by using a relatively interventionist exchange rate policy. Their central banks may want to announce a long-term commitment to either a hard exchange rate or a full-fledged inflation target to bring forward the benefits of a single-anchor monetary regime. In his comments, Jerzy Pruski (National Bank of Poland) described inflation targeting lite as a means of buying time to make the structural reforms needed for adopting a single nominal anchor.

For a small open economy, the central banks' role in managing both international debt and reserves provides an important element of financial stability as discussed for the case of Denmark by Hugo Frey Jensen (National Bank of Denmark). Central bank responsibility for both debt and reserve management is an efficient way to utilize scarce resources in a small country and establishes knowledge of most aspects of the financial markets within a single institution. Potential conflicts between monetary policy and public debt management are, however, mostly of concern for countries with a floating exchange rate, as was noted by Michael Reddell (Reserve Bank of New Zealand), who described New Zealand's experience.

However, should financial stability be an explicit central bank objective on par with other objectives? Roger W. Ferguson, Jr. (Board of Governors, U.S. Federal Reserve System) noted that the U.S. central bank views its financial stability objectives primarily through the lens of its macroeconomic goals_-price stability and sustainable long-run growth. Today, he said, it is more important than ever for central banks and other financial authorities to share information, coordinate crisis prevention measures, and cooperate in crisis management actions.

In Ferguson's view, some of the more urgent central bank issues are whether a central bank should take preemptive actions to head off potential financial instability, even when such policy actions may not be fully justified by the outlook for inflation and output; how much weight to give to finan- 
cial stability versus other objectives; and whether a high degree of activism could lead to higher variability of economic variables. In his comments, André Icard (Bank for International Settlements) came down on the side of more central bank activism in financial stability concerns, although he did stress the potential difficulties arising from the shorter time horizon that exists for monetary objectives than for financial objectives, as well as the risk of moral hazard.

The role of financial soundness indicators (FSIs) in crisis prevention was discussed by V. Sundararajan (IMF) and R. Sean Craig (IMF). Their paper outlined the need for an integrated framework that links three key dimensions of financial stability. First, FSIs can be used to monitor the financial system's strengths and vulnerabilities and the risks originating in the nonfinancial sector. Second, codes and standards assessments of the supervisory framework and the financial infrastructure provide important information to assess financial sector stability. Third, the analysis of FSIs can help to highlight the key prudential risks and vulnerabilities on which the scope and themes of supervision and its assessments should focus. An example of how a central bank assesses financial stability was given by Jarle Bergo (Bank of Norway). The Bank of Norway uses FSIs for the financial and nonfinancial sectors and links them to macroeconomic models to make forecasts and perform stress tests.

Finally, Mario Blejer (Governor of the Central Bank of Argentina, January-June 2002) provided a lively, first-hand account of what transpires on the frontlines of a financial crisis. According to Blejer, the collapse of Argentina's peso had its roots in inconsistencies between the currency board and the country's fiscal stance. The subsequent banking crisis was largely caused by sovereign risk and by the government forc- ing the banks to hold government securities at below market prices.

In November 2001, Argentina imposed partial withdrawal restrictions for deposits (the corralito), abandoned the currency board, devalued the currency, and "pesoified" bank assets and liabilities at different rates. While pesoification put the central bank in a position to act as a lender-of-last resort, it had no money market or debt instruments to sterilize open market operations. Therefore, the central bank introduced short-term central bank papers in pesos and dollars. With the central bank stressing the risk differences between its instruments and those of the rest of the public sector, a demand for these papers developed, even though it was initially at very high costs for the central bank in interest rates of up to 140 percent. Meanwhile, the central bank kept up payments on its own foreign obligations and intervened in the foreign exchange market to slow the pace of depreciation and avoid chaotic conditions. By mid-June 2002, Blejer noted, the trends started to reverse. Thereafter, deposit withdrawals slowed; the need for liquidity from the central bank largely declined; central bank interest rates fell to 40-50 percent; and the central bank regained about half of the initial stock of foreign reserves. The bottom line for a central bank in crisis, Blejer said, is to persevere to the point where "greed exceeds panic" providing investors with high-enough returns makes them forget the panic. Another account of the challenges in handling a financial crisis was given by Kyu Yung Chung (Bank of Korea), who reported on the lessons from the Korean crisis.

The conference papers are posted at the Research at the IMF website at http://www.imf.org/research. Follow the link to IMF Seminar, Conferences, and Workshops.

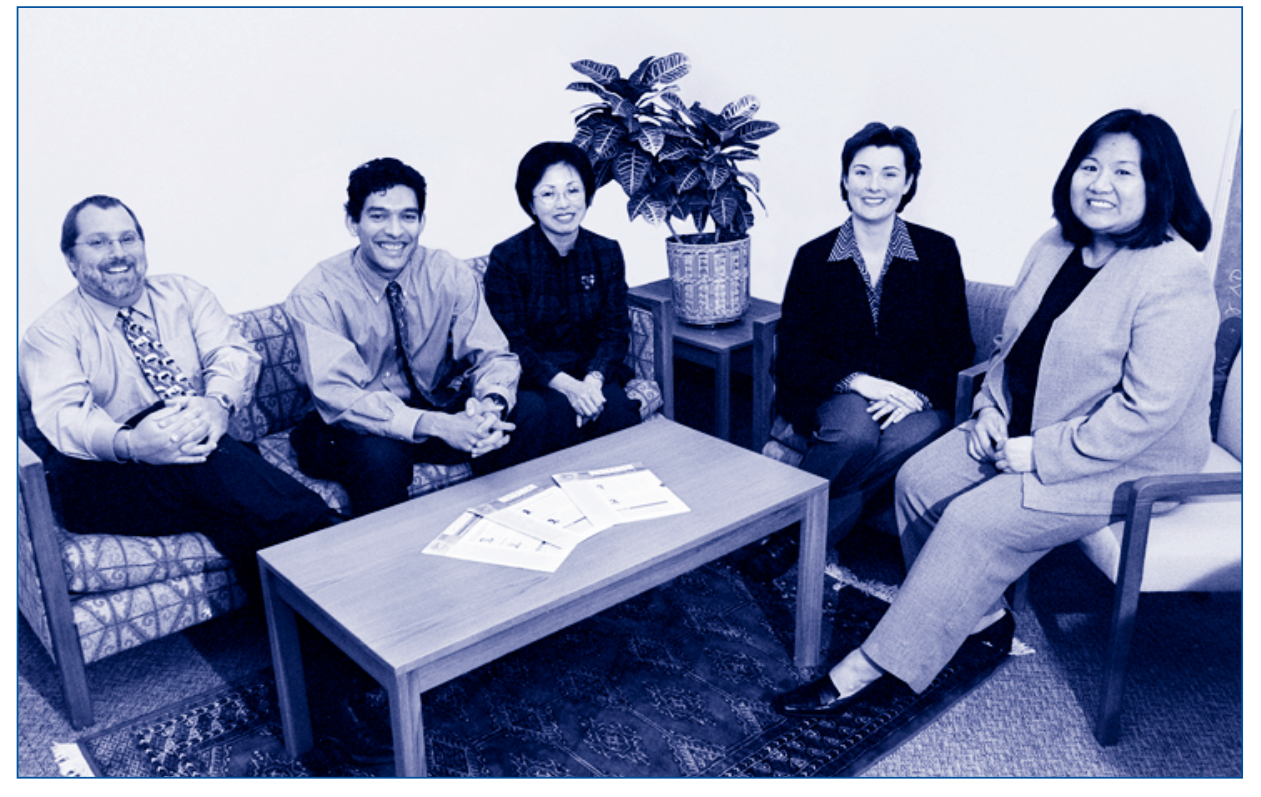

The IMF Research Bulletin Editorial and Production Team: Phil Torsani, Eswar Prasad, Choon Lee, Dawn Heaney, Helen Chin, Kellett Hannah (not in photo). 


\section{Globalization in Historical Perspective}

Summary by Wayne Camard

The IMF Institute hosted a conference on August 12-14, 2002, featuring officials from some fifty IMF member countries, who had been invited to participate in a continuing dialogue on Globalization in Historical Perspective, which first began at an NBER conference in May 2001. Participants focused on the century before the First World War in an effort to discern lessons for the modern era about how trade and international factor movements affect inequality and reshape the global economic landscape. Researchers found similarities between the pre-WWI and modern periods, suggesting that a political backlash against globalization, akin to that of the early twentieth century, was a real possibility today. At the same time, they also presented evidence that globalization today is a more inclusive and humane process than it was a century ago.

Anne Krueger (IMF) opened the conference with these words: "If we fear that the violent political reaction to globalization seen recently in Seattle, Ottawa, Gothenberg, and Genoa might cause a political retreat from liberal policy, then it would pay to look carefully at the twenty years or so before World War I." Indeed, as Ms. Krueger suggests, the increase in globalization-global integration-during the nineteenth century, which was driven by the new technologies of the steamship and the telegraph, may have carried the seeds of its own destruction through its effects on the distribution of income across and within countries.

\section{Globalization Before World War I}

Ronald Findlay (Columbia University) set the stage by saying that the voyages of discovery of Christopher Columbus and Vasco da Gama marked the true beginnings of globalization, noting the explorers' desire to break the Venetian/Egyptian monopoly over trade with Asia. The three centuries that followed Columbus saw an increase over time in the range of goods that were traded, and trade grew by about 1 percent per year, well above the average of 0.3 percent GDP growth.

Jeffrey Williamson (Harvard University) disagreed with this characterization. To him, the sixteenth through eighteenth centuries were a period of antiglobalization mercantilist policies and growing income inequality. Rising population raised the scarcity value of land, and the incomes of wealthy landowners, relative to the farm wage. The rising trade share in GDP simply reflected the fact that trade in the period consisted almost entirely of luxury goods that the rich-alone-could increasingly afford.

True globalization, he said, began only during the nineteenth century, with the unleashing of the economic forces that foster factor price equalization, particularly wage convergence: trade, migration, and capital flows. Britain's nineteenth-century freetrade leadership, especially the 1846 repeal of the Corn Laws, played an important part in the globalization of the period.

Labor flows in this period were especially large, particularly after 1870: by 1910, migration had increased the U.S. labor force by a quarter - far more in Canada, Australia, and Argentinawhile reducing it in Europe, by nearly half in Italy and Ireland, and by one-eighth for Western Europe as a whole. Indeed, close to 70 percent of the convergence in wages that took place in the Atlantic world over this forty-year period is explained by labor migration, with capital mobility having little impact on relative wages.

While the impact of capital flows on income convergence was modest at best, that is not to say the flows were not large. Alan Taylor (University of California-Davis) traced the rise of the international capital markets, beginning with the large-scale financing of British military expenditure by the Dutch during the Napoleonic Wars.

Capital flows became particularly important for the United States, arguably the first successful emerging market. Indeed, as Richard Sylla (New York University) postulated, Alexander Hamilton's financial reforms, including the settlement at par of Revolutionary War debt, were instrumental to U.S. economic development in the nineteenth century.

Michael Bordo (Rutgers University) presented a comparison of the classical gold standard and the post-Bretton Woods system of floating exchange rates. He emphasized that an economy's financial maturity (and the credibility of its policies) is more important to stability than its exchange regime, then as now. To Bordo, financial crises are an unfortunate but inevitable part of "growing up" for emerging markets.

The massive migrations during the 1870-1914 period reduced the returns to landowners in the land-scarce, labor-abundant countries of Europe and worsened the income distribution in the countries of new settlement, because unskilled workers were competing with more established workers for jobs. In the Old World, the landowners successfully lobbied for increased tariff protection for agriculture during the last decades of the nineteenth century.

In the New World, labor was ultimately successful in closing the door to migrants by the second decade of the twentieth century.

\section{Lessons for the Twenty-First Century}

Are the same economic forces contributing to a backlash against globalization today? The growth of international trade today is more widespread, so the benefits of trade are more widely shared, and losers are better protected by national social policies. International immigration does remain an important issue, and Barry Chiswick (University of Illinois at Chicago) suggested that the result of current trends may be greater income convergence by skill level across the globe even as inequality rises within countries. This will result in increasing pressure to prevent illegal immigration. A final but very important difference is that most countries in recent years have learned to pursue stable macroeconomic policies, in sharp contrast to the very unstable environment that led to the shutting down of the capital markets in the interwar period. Professor Bordo, for one, was optimistic about the current wave of globalization, closing the proceedings with the view, "Other parts of the world are going to get rich.”

The papers presented, along with others on the subject, are available at the NBER website at http://www.nber.org/books/global. 


\section{IMF Working Papers}

Working Paper No. 02/111

Forecasting Inflation in Indonesia

Ramakrishnan, Uma; Vamvakidis, Athanasios

Working Paper No. 02/112

Aid and Fiscal Management

Bulir, Ales; Lane, Timothy D.

Working Paper No. 02/113

In Finance, Size Matters

Bossone, Biagio; Lee, Jong-Kun

Working Paper No. 02/114

Poverty in a Wealthy Economy: The Case of Nigeria

Thomas, Saji; Canagarajah, Sudharshan

Working Paper No. 02/115

Limits of Conditionality in Poverty Reduction Programs

Cordella, Tito; Dell'Ariccia, Giovanni

Working Paper No. 02/116

Assessing Monthly Progress Towards Annual Fiscal

Revenue Targets

Kanda, Daniel S.

Working Paper No. 02/117

It's Not What You Make, It's How You Use IT: Measuring the Welfare Benefits of the IT Revolution Across Countries

Bayoumi, Tamim A.; Haacker, Markus

Working Paper No. 02/118

Is Growth Enough? Macroeconomic Policy and Poverty Reduction

Ghura, Dhaneshwar; Leite, Carlos A.; Tsangarides,

Charalambos

Working Paper No. 02/119

Demutualization of Securities Exchanges: A Regulatory

Perspective

Elliott, Jennifer

Working Paper No. 02/120

Capital Account Liberalization and Economic Performance: Survey and Synthesis

Edison, Hali; Klein, Michael; Ricci, Luca A.; Slok, Torsten M.

Working Paper No. 02/121

Labor Market Pooling

De Blasio, Guido; Di Addario, Sabrina

Working Paper No. 02/122

Collateral in Loan Classification and Provisioning

Song, Inwon
Working Paper No. 02/123

Migration and Human Capital Formation: Theory and Evidence from the U.S. High School Movement

Ramcharan, Rodney

Working Paper No. 02/124

Some International Issues in Commodity Taxation

Keen, Michael J.

Working Paper No. 02/125

Internal Models-Based Capital Regulation and Bank RiskTaking Incentives

Kupiec, Paul H.

Working Paper No. 02/126

Seductions of an Underdevelopment Trap: Systemic Impediments to Agricultural Reform in Russia Amelina, Maria; Gershenson, Dmitry

Working Paper No. 02/127

Lithuania: History and Future of the Currency Board Arrangement

Alonso-Gamo, Patricia; Fabrizio, Stefania; Kramarenko, Vitali; Wang, Qing

Working Paper No. 02/128

Intergovernmental Grants Systems and Management: Applications of a General Framework to Indonesia Ahmad, S.E.; Ma, Jun; Searle, Bob; Piperno, Stefano

Working Paper No. 02/129

Treasury Reform in Kazakhstan: Lessons for Other Countries Ramamurthy, S.; Tandberg, Eivind

Working Paper No. 02/130

Current Account and Real Exchange Rate Dynamics in the G-7 Countries

Chinn, Menzie; Lee, Jaewoo

Working Paper No. 02/131

Will There Be New Emerging-Market Economies in Africa by the Year 2020?

Berthelemy, Jean-Claude; Soderling, Ludvig

Working Paper No. 02/132

The Speed of Adjustment and the Sequencing of Economic Reforms: Issues and Guidelines for Policymakers

Nsouli, Saleh M.; Rached, Mounir R.; Funke, Norbert

Working Paper No. 02/133

Bankruptcy Procedures for Sovereigns: A History of Ideas, 1976-2001

Rogoff, Kenneth; Zettelmeyer, Jeromin 
Working Paper No. 02/134

Regional Labor Market Disparities in Belgium

Estevao, Marcello

Working Paper No. 02/135

Changes in the Structure of Earnings During the Polish Transition

Keane, Michael; Prasad, Eswar S.

Working Paper No. 02/136

Indonesia: Managing Decentralization

Ahmad, S.E.; Mansoor, Ali M.

Working Paper No. 02/137

Central Bank Financial Strength, Transparency, and Policy Credibility

Stella, Peter

Working Paper No. 02/138

Liberalization of Trade in Financial Services and Financial Sector Stability (Analytical Approach)

Kireyev, Alexei P.

Working Paper No. 02/139

Liberalization of Trade in Financial Services and Financial
Kireyev, Alexei P.

Working Paper No. 02/140

Issues in Domestic Petroleum Pricing in Oil-Producing Countries

Gupta, Sanjeev; Clements, Benedict J.; Fletcher, Kevin T.; Inchauste, Gabriela

Working Paper No. 02/141

Liability Dollarization and the Bank Balance Sheet

Channel

Choi, Woon Gyu; Cook, David H.

Working Paper No. 02/142

Fiscal Consequences of Armed Conflict and Terrorism in Low- and Middle-Income Countries

Gupta, Sanjeev; Clements, Benedict J.; Bhattacharya, Rina; Chakravarti, Shamit

Working Paper No. 02/143

Wage Centralization, Union Bargaining, and

Macroeconomic Performance

McHugh, James E.

Working Paper No. 02/144

Spreading Currency Crises: The Role of Economic

Interdependence

Berger, Wolfram; Wagner, Helmut
Working Paper No. 02/145

International Financial Integration and Economic Growth Edison, Hali; Levine, Ross; Ricci, Luca A.; Slok, Torsten M.

Working Paper No. 02/146

Determinants of Commercial Bank Performance in Transition: An Application of Data Envelopment Analysis Grigorian, David A.; Manole, Vlad

Working Paper No. 02/147

The Rise in Comovement Across National Stock Markets: Market Integration or Global Bubble?

Brooks, Robin J.; Del Negro, Marco

Working Paper No. 02/148

Trade and Integration in the Caribbean

Egoume Bossogo, Philippe; Mendis, Chandima

Working Paper No. 02/149

Sovereign Defaults: The Role of Volatility

Catao, Luis A.; Sutton, Bennett W.

Working Paper No. 02/150

Are Mexican Business Cycles Asymmetrical?

Santos, Andre O.

Working Paper No. 02/151

Wage Moderation in France

Estevao, Marcello; Nargis, Nigar

Working Paper No. 02/152

Corporate Performance and Governance in Malaysia

Khatri, Yougesh; Leruth, Luc E.; Piesse, Jenifer

Working Paper No. 02/153

Growth in Switzerland: Can Better Performance Be Sustained?

Gagales, Anastassios

Working Paper No. 02/154

Asian Flu or Wall Street Virus? Price and Volatility Spillovers of the Tech and Non-Tech Sectors in the United States and Asia

Chan-Lau, Jorge; Ivaschenko, Iryna V

Working Paper No. 02/155

The Evolution of Exchange Rate Regimes Since 1990: Evidence from De Facto Policies

Bubula, Andrea; Otker-Robe, Inci

Working Paper No. 02/156

The Determinants of On-the-Job Search: An Empirical Exploration

Fuentes, Andres 
Working Paper No. 02/157

Internal Models, Subordinated Debt, and Regulatory

Capital Requirements for Bank Credit Risk

Kupiec, Paul H.

Working Paper No. 02/158

The Africa Growth and Opportunity Act and Its Rules of Origin: Generosity Undermined?

Mattoo, Aaditya; Roy, Devesh; Subramanian, Arvind

Working Paper No. 02/159

Microfinance Institutions and Public Policy

Hardy, Daniel C.; Holden, Paul; Prokopenko, Vassili

Working Paper No. 02/160

How Competitive Is Irish Manufacturing?

Cerra, Valerie; Soikkeli, Jarkko

Working Paper No. 02/162

Politics, Government Size, and Fiscal Adjustment in Industrial Countries

Annett, Anthony M.

Working Paper No. 02/164

On Sand and the Role of Grease in Labor Markets: How

Does Germany Compare?

Decressin, Anja; Decressin, Jorg W.

Working Paper No. 02/165

An Empirical Investigation of Exchange Rate Pass-Through in South Africa

Bhundia, Ashok J.
Working Paper No. 02/166

Exchange Rate Responses to Inflation in Bangladesh

Hossain, Akhtar

Working Paper No. 02/167

Statistical Treatment of "Build-Own-Operate-Transfer"

Schemes

Donaghue, Brian T.

Working Paper No. 02/168

Recentralization in China?

Ahmad, S.E.; Keping, Li; Richardson, Thomas J.;

Singh, Raju J.

Working Paper No. 02/169

Transition and Regional Inequality in Russia:

Reorganization or Procrastination?

Dolinskaya, Irina

Working Paper No. 02/170

Sovereign Credit Ratings Methodology: An Evaluation Bhatia, Ashok Vir

Working Paper No. 02/171

The Missing Globalization Puzzle

Coe, David T.; Subramanian, Arvind; Tamirisa, Natalia T.;

Bhavnani, Rikhil

IMF Working Papers and other IMF publications can be downloaded in full-text format from the Research at the IMF website: http://www.imf.org/research.

\section{Visiting Scholars, July-September 2002}

Adeboye Adeyemo; University of Ibadan, Nigeria

Yaw Asante; University of Ghana, Ghana

Ricardo Caballero; Massachusetts Institute of Technology

Daniel Cohen; University of Paris, France

Betty Daniel; The University of Albany, N.Y.

Emmanuel Douya; University of Yaounde II, Cameroon

Allan Drazen; University of Maryland

Charles Engel; University of Wisconsin

Kristin Forbes; Massachusetts Institute of Technology

Petra Geraats; University of Cambridge, United Kingdom

Calvin Ying-Shun Ho; University of California-Berkeley

David Hummels; Purdue University

Graciela Kaminsky; George Washington University

Kala Krishna; Pennsylvania State University

Arvind Krishnamurthy; Northwestern University
Oludoton Lawanson; University of Ibadan, Nigeria

Ronald MacDonald; University of Strathclyde, United Kingdom

Anke Maselli; German Savings Banks Association, Germany Christopher Otrok; University of Virginia

Jean Remy Oyaya; Institute of Economics \& Finance, Gabon Andrew Powell; University Torcuato Di Tella, Argentina Sergio Rebelo; Northwestern University

Lee Redding; University of Glasgow, United Kingdom Roberto Rigobon; Massachusetts Institute of Technology Xavier Sala-I-Martin; University Pompeu Fabra, Spain Sekou Sangare; University of Cocody-Abidjan, Cote d'Ivoire

Mark Taylor; Warwick University, United Kingdom Carlos Vegh; University of California-Los Angeles 


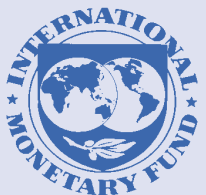

IMF Research Bulletin

Eswar S. Prasad

Editor

Helen Chin

Assistant Editor

Kellett Hannah

Systems Consultant

Choon Lee

Typesetting

Phil Torsani

Graphic Designer

Dawn Heaney

Editorial Assistant

The IMF Research Bulletin (ISSN: 1020-8313) is a quarterly publication in English and is available free of cost. Material from the Bulletin may be reprinted with proper attribution. Editorial correspondence may be addressed to The Editor, IMF Research Bulletin, IMF, Room 10-700, Washington, DC 20431 U.S.A. or e-mailed to resbulletin@imf.org. Subscription requests should be addressed to Publication Services, Box X2001, IMF, Washington, DC 20431 U.S.A.; e-mail: publications@imf.org.

\section{World Economic Outlook, September 2002}

\author{
Summary by Thomas Helbling
}

In addition to the widely known, comprehensive review of recent global developments, prospects, risks, and policy recommendations, the latest IMF World Economic Outlook (WEO) also includes two analytical chapters on trade and its links with finance-topical issues that should be of interest to both analysts and policymakers. This article summarizes the analytical work contained in the September 2002 WEO.

The main analytical chapter of the latest WEO focuses on the interaction between trade and financial integration. Historical experience suggests that international trade integration and international financial integration tend to move together over time and across countries. In the last major episode of globalization, from 1870 to 1914, advances in transportation and communication technology drove international economic integration, while policy liberalization is the main force in the current period. With policy liberalization largely driving integration now, the sequencing of policy reforms, thus, matters. Based on the empirical analysis of integration patterns for trade and finance, and their effects on the risks of external financial crises and macroeconomic volatility, the WEO states that integration in both the trade and financial domains is necessary to reap the full benefits of globalization. With unbalanced integration, benefits are smaller and risks are greater, as recent cases of financial integration leaping ahead of trade integration have shown. Given this experience, a gravity model is used in the main analytical chapter to look at the major factors determining levels of merchandise trade.

The WEO's second analytical chapter contains three essays on topical issues related to trade and finance. The first essay examines whether current external imbalances are worrisome or not. It is argued that policymakers should continue to be concerned about current accounts despite recent discussions of their irrelevance. A trade balance adjustment of just a few percentage points of GDP may require significant changes in the tradable goods sector and lead to large and possibly disruptive exchange rate movements. After analyzing the evolution of external imbalances during the 1990s, from a multilateral perspective, the essay concludes that current levels of current account deficits and surpluses are not viable over the medium term. While macroeconomic policies should not target current account balances directly, the essay emphasizes that policies should, nevertheless, try to minimize the risk of rapid and disruptive current account adjustments. In deficit countries, this would mean credible medium-term fiscal consolidation is called for whereas, in surplus countries, authorities should press ahead with needed structural reforms to foster growth.

The second essay looks at how agricultural policies of industrial countries affect developing countries. The essay provides detailed, partial, and general equilibrium analyses of the welfare costs of agricultural support policies, more broadly and for specific commodities. The main conclusion is that removing agricultural support in industrial countries would raise world real income by at least $\$ 100$ billion a year, with most of the gains accruing to industrial countries. Developing countries would also gain, in an amount equal to one sixth of global aid flows. The removal of agricultural supports in developing countries would confer even larger benefits to the developing world. The importance of removing supports by a multilateral method is underscored. The essay also argues that industrial countries are best placed to take the lead in agricultural trade liberalization, given their wealth and the small size of their agricultural sectors.

The third essay is a study of corporate financial structure across emerging markets. An analysis of related indicators in 18 emerging market economies finds that corporations in east Asian emerging mrkets have substantially higher ratios of debt to assets, and debt to equity, than Latin American and emerging European corporates. The east Asian corporations also tend to rely more on short-term debt. Detailed empirical analysis of main determinants finds the two most important factors in explaining differences in corporate health indicators across emerging market regions. First, as financial systems develop, corporate leverage tends to rise first, as corporates find it easier to borrow. Equity financing by corporates usually only increases at more advanced stages of financial development. Second, firms in emerging market economies that are more open to foreign investors will tend to find it easier to sell equity and reduce their dependence on shorter-term domestic debt. 